\title{
Současné vnímání sportu vysokoškolskou mládeží
}

\section{Current perception of sports by university youth}

\author{
Zdeněk Valjent \\ Ústav tělesné výchovy a sportu, ČVUT v Praze \\ Libor Flemr \\ Fakulta tělesné výchovy a sportu Univerzity Karlovy v Praze
}

\begin{abstract}
Abstrakt
V krátké studii jsme chtěli zjistit odpověd' na otázku,,Jak vysokoškolští studenti technické univerzity vnimaji sport”. K zodpovězeni této otázky jsme použili jednak Likertovu škálu s 11 bodovou stupnici (-5 až +5), pro dalši bližši vnímáni kladů a záporů rekreačního a vrcholového sportu pak i kvalitativní výzkum - metodu analýzy osobnich dokumentů. Dokumentem v tomto př́padě se staly volné odpovědi a ničím neohraničené názory studentů $k$ tomuto tématu.

Studenti ČVUT vnímaji pojem sportu velice kladně a to průměrem na škále $+3,15$. Vyjádřili celkově 1342 stanovisek k rekreačnímu a vrcholovému sportu, což činí prüměr 9,2 vyjádření na jednoho. Na adresu rekreačního sportu jich bylo celkově 449 kladných oproti 185 záporným. Studenti zde jasně vyjmenovali všechny hlavní klady rekreačního sportu - nezávislost, volnost a časovou flexibilitu, zábavu, relaxaci a udržení fyzické kondice; naznačili však i jeho největši nedostatky - finanční a časovou náročnost, možnost zranění. Na vrcholovém sportu našli 340 pozitivnich proti 368 negativním znakům. Za klady studenti považují jeho př́nosy pro rozvoj morálněvolních vlastností, vysokou kondični připravenost, možnost vysokých finančních výdělků a také všechny kolektivní zážitky. Plně si však uvědomuji i hlavní negativa - zdravotni problémy, jednostranné životni zaměření, problémové morální a společenské aspekty.
\end{abstract}

\begin{abstract}
We were looking for an answer for a question "How do students of a technical university perceive sports" in a short survey. To answer this question we used Likert scale with 11 levels $(-5$ to +5$)$. To evaluate pros and cons of recreational and professional sports more closely in terms of quality-method of analysing personal documents were used. Documents considered in this case were free answers and non-bounded opinions of students to this topic.

CTU students perceive sports in a very positive manner. Average ranking of +3.15 on the scale. They expressed 1342 statements concerning recreational and professional sports. It's 9.2 statements per student in average. There were 449 positive to 185 negative statements addressing recreational sports. Students clearly declared all of the main positive aspects of recreational sports. Independency, freedom and time flexibility, fun, relaxation and maintaining physical condition. They also outlined some major disadvantages as financial and time demands and injury probabilities. Students found 340 positive and 368 negative features of professional sports. Some of the positive features were described as development of moral qualities, highly maintained physical condition, the possibility of high financial incomes and social experience. They are also fully aware of the main drawbacks - health problems, one and only main life focus, problematic moral and social aspects.
\end{abstract}

Klíčová slova: rekreační sport, vrcholový sport, postoje, studenti, technická univerzita

Key words: recreational sport, professional sport, attitudes, undergraduates, Technical university

Úvod

V poslední době jsme svědky debat, jak mezi vysokoškolskými studenty, tak také mezi vysokoškolskými pedagogy (ale i širokou veřejností), na téma ,současné vnímání sportu vysokoškolskou mládeži”. Při těchto debatách se nezřídka objevují názory některých debatujících, že dnešní mládež již sport nepřijímá tak kladně, jako kdysi, že si již plně uvědomuje i jeho velká negativa vztahující se převážně k vrcholovému sportu a jeho 
komerčnímu využití. Rozhodli jsme se, že se pokusíme zjistit názory studentů ČVUT v Praze. K tomu jsme použili následující průzkum pomocí dotazování.

Ve vědecké literatuře se píše o neoddiskutovatelných bio-psycho-sociálních přínosech sportu. Účinky sportu však mohou být jak pozitivní, tak i negativní. Záleží na úhlu pohledu. Tento pohled se přirozeně bude lišit dle různých kultur, jelikož každá kultura preferuje rozdílné hodnoty (Flemr, Valjent, 2010).

O významném a de facto nezastupitelném postavení pohybových, respektive sportovních, aktivit pojednává řada dokumentů na mezinárodní úrovni - „Evropská charta sportu pro všechny“ (1974, in Králík, 2001), „Mezinárodní charta tělesné výchovy a sportu“ (1978, in Králík, 2001), „Evropská deklarace urbanistických práv“ (MŠMT, 1992), „Evropská charta sportu“ (MŠMT, 1994), „Evropský manifest o mladých lidech a sportu“ (MŠMT, 1995), „Modifikovaný návrh směrnic pro sport dětí a mládeže“ (ČSTV, 1998) Evropského sdružení národních nestátních sportovních zastřešujících organizací (European Non-Governmental Sports Organisations), „Světový manifest tělesné výchovy 2000“; „Bílá kniha o sportu“ (MŠMT, 2007). V českých podmínkách jde např. o různá vládní usnesení, která se stala základem pro zákon o podpoře sportu. Z dalších vládních dokumentů lze uvést především materiál Ministerstva školství, mládeže a tělovýchovy (MŠMT) „Směry státní politiky na léta 2004-2006“ aj. Mnohé české výzkumy (např. Zich a Ungr, 1995; Slepička, 2000; Rychtecký et al., 2000, 2001; Kavalíŕ, 2003) potvrzují význam sportu v hodnotové orientaci zejména mladé generace i současné vysoké zastoupení sportu mezi aktivitami provozovanými ve volném čase. Dle Jansy (2002) si více než 73 \% české mládežnické populace (15-18 let) uvědomuje důležitost sportu a pohybových aktivit z celospolečenského hlediska, tzn. pro všechny věkové skupiny obyvatel.

Na významnost sportu v celospolečenském kontextu poukazují mnohé zahraniční studie. Např. podle Weisse (2000) sport zrcadlí společnost a může do určité míry přispívat k jejím proměnám. Nejen při velkých sportovních událostech, ale i při masovém sportování (např. zejména ve skandinávských zemích, kde je sport jedním z klíčových atributů tamního životního stylu, ale i v C̆R) lze o sportu bez nadsázky mluvit jako o společenském fenoménu (např. Sekot, 2007).

Nutno zde připomenout, že především rekreační sport má především kladné společenské účinky včetně vlivu na osobnost každého jedince, což vyplývá především z toho faktu, že sám tvoří jednu z přirozených složek volného času. Ne tak jednoznačné je to ale s vrcholovým sportem, kde můžeme být svědky i mnoha negativních jevů. Pokud je sportovní činnost uskutečňována na úkor všestrannosti individuálních př́íležitostí, znalostí a vědomostí, zkušeností a vztahů, pak lze předpokládat negativní socializační důsledky (Sekot, 2003).

Některá negativa vrcholového sportu uvádí Okamura (2011): - v posledních desetiletích profesionální sport degradoval, nebo popravdě řečeno, spíš se vrátil ke svým gladiátorským kořenům; - neslouží zdraví, naopak, dělá ze sportovců doživotní mrzáky anebo je rovnou zabíjí; - podplácí se, kde to jde; - týmy "lékařů a vědcư“ vyvíjí a aplikují výkonnější a nepoznatelnější drogy k vybičování sportovcova organismu; - politici, úředníci a podnikatelé tu profitují z veřejných zakázek spojených s konáním monstrózních akcí a platí to daňoví poplatníci; - sledování sportu v televizi zabíjí čas a nepředává žádnou informační hodnotu; - výrazná část diváků pak pravidelně podlehne adrenalinu a jde masakrovat jiné diváky, o jejichž bezpečí se pak za peníze všech občanů stará policie.

\section{Cíl studie}

Z úvodu je patrné, že ve společnosti existují jasně pojmenované př́nosy i zápory sportu. Cílem této studie je pak zjistit, jak sport vnímají studenti ČVUT v Praze.

\section{Metodika}

Kvalitativní výzkum metodou analýzy osobních dokumentů byl proveden na vzorku 146 studentů všech ročníků prezenční formy studia a všech fakult ČVUT v Praze. Studenti byli ve věku 19 - 27 let, z nichž bylo 95 chlapců (65 \%) a 51 dívek (35 \%). Byl realizován v srpnu a prosinci roku 2011. Výběrový soubor byl vybrán tak, aby se jej zúčastnili co nejvíce různorodí studenti a zastupovali tak celkový vzorek studentů ČVUT. Proto sem byla vybrána skupina studentů absolvujících letní výcvikový kurz v Chorvatsku; oddíl studentů chodících v zimním semestru 2011/12 na plavání (jako vytrvalostní sport); na kondiční posilování (nárůst síly); bowling (herní zážitky); aerobic (“dívčí sport”); kondiční přípravu ,Záchranářù” (TV jako oborový předmět) a skupina studentů osvobozených od TV (předpokládané negativnější názory na sport). 
Studenti byli vyzváni, aby zaznamenali na připravený papír své odpovědi na dvě otázky:

1. "Pojem „sport“ bez dalšího bližšího určení ve vaší mysli okamžitě vyvolá určitou kladnou či zápornou odezvu (pocit, vjem). Vyznačte křížkem sílu vašeho pocitu na následující

11 stupňové Likertově škále od hodnoty ,,- 5 “ („,maximálně ho nemám rád-a“) přes „,0“ (,,ani to ani to“) až k hodnotě „,+5“ („maximálně ho mám rád-a“).

2. Sami cítíte, že k tomuto hodnocení by se patřilo provést ještě bližší vysvětlení. Proto se pokuste charakterizovat krátkými a výstižnými slovy klady a zápory rekreačního a vrcholového sportu.

Každý ze studentů si pak v průběhu hodiny zaznamenával své myšlenky (názory) na přidělený papír, aniž by mu byl nabídnut jakýkoliv výběr odpovědí. Na konci hodiny pak všichni studenti papíry odevzdali na určené místo, čímž zde byl zachován požadavek anonymity. Někteří studenti také odpovědi poslali E-mailem.

Z odpovědí na 1 . otázku byl vypočítán aritmetický průměr, který zde vyjadřuje tzv. průměr na škále. Jednotlivá vyjádření studentů vztahující se ke kladům a záporům rekreačního a vrcholového sportu byla zaznamenávána do předem připravených kategorií (Svoboda, 1971; Valjent, 2007).

\section{Výsledky a diskuze}

\section{A. Pojem sport}

Na 1. otázku odpověděli studenti: jedenkrát (- 4); jedenkrát $(-3) ; 8 \times(0) ; 8 \times(+1) ; 20 \times(+2) ; 37 \times(+3)$; 39 x $(+4)$ a 32 x (+5). Průměr na škále proto činil $(+\mathbf{3 , 1 5})$. Kromě několika jednotlivců mají studenti ke sportu obecně velmi pozitivní vztah.

\section{B. Klady rekreačního sportu (vyjmenovaná vyjádření studentů roztř́děná do kategorií) \\ 1. Postoje $k$ individuální nezávislosti a volnosti}

Sportuji kdy chci, kde chci ...(20x); Časová flexibilita a nezávislost (10x); Kdykoliv se mi hodí (3x); Zbude více volného času (4x); Sám si vyberu, kolik a jak budu cvičit (9x); Provozuje se v množství, které nám vyhovuje (2x); Nepřetěžování (2x); Možnost vyzkoušet úplně vše (2x); Výběr z několika sportů (2x); Pestrost cvičení (2x); Možnost vyzkoušet si něco nového; Náročnost si určím sama; Variabilita; Nezávislost na jiném člověku (2x); Volnost (2x); Pod kontrolou sportovce; Záleží na chuti; Svobodné rozhodování; Upř́ímnost.

\section{Celkem 67 vyjádření.}

\section{Bližší kladná charakteritika rekreačního sportu}

Smysluplné vyplnění volného času (5x); Zpestření volného času (2x); Př́ijemně strávený čas; Lepší využití času než u počítače a televize; Nenásilná forma pohybu (2x); Může ho vykonávat každý bez ohledu na to, jestli mu to jde (2x); Neunaví tolik (2x); Žádné zranění;

Není závazný (2x); Nemá psychické vypětí; Nikdo mi nenadává; Dostupné všem (4x); Méně nákladné; Nestojí tolik peněz (2x); Lepší než žádný sport (2x); Přístupný pro různé věkové skupiny (2x); Cvičení i s dětmi; Není potřeba profi pomůcek ani profi centra (3x); Nepotřebuji pravidelný trénink; Umožňuje profitovat svou osobnost; Dává téma k hovoru; Změna školního stereotypu; Pro osobní rozvoj; Správná morálka; Vyrovnaný styl života; Čas být sám; Změna stereotypů při práci; Životní styl; Dělám něco pro sebe; Ve zdravém těle zdravý duch; Objevování přírody; Čerstvý vzduch; Cestování.

Celkem 50 vyjádření.

\section{Postoje k zábavě, sociálnímu kontaktu, přátelství}

Zábava (59x); Zábava i v zimě; Dobrá nálada (2x); Forma setkání s přáteli (8x); Přátelé (7x); Kolektiv (6x); Pobavení se známými (2x); Sociální vazby $(2 x)$; Neomezování v rámci týmu; Kamarádi; Poznávání nových lidí (7x); Noví známí (3x); Spřátelení; Setkání s příznivci stejného sportu; Holky; Seznámení s druhým pohlavím seznamka; Poznávání nových míst (3x); Poznávání nových možností.

\section{Celkem 107 vyjádření.}

\section{Postoje k relaxaci, kompenzaci, snižování tenze, radosti z pohybu}

Zlepšení nálady (4x); Zlepšení psychického stavu (2x); Díky tomu zlepšení psychiky; Zvýšení duševní pohody (4x); Dobrý pocit (7x); Př́ijemný pocit (2x); Pro radost; Odreagování (24x); Relaxace (17x); Uvolnění (8x); Pročištění hlavy (5x); Radost a pocit, že pro sebe něco dělám (3x); Odpočinek (3x); Odreagování od denních starostí; Uklidnění; Dobrý tělesný i duševní pocit; Aktivní odpočinek (7x); Celkový dobrý fyzický pocit; Protažení těla; Tělesná pohoda; Můžeme se při tom rekreovat; Oddych; Pomáhá k optimismu; Uvolnění a odbourání stresu (7x); Ventilace problémů; Vybití se; Vybití energie; Občas adrenalin; Vypuzení adrenalinu; Vyplavení endorfinů; Lepší spánek.

Celkem 111 vyjádření. 


\section{Postoje k zdatnosti, zdraví a dokonalému vzhledu}

Udržování kondice (23x); Zlepšení fyzické kondice (17x); Dobrá fyzická kondice (11x);Formuje postavu (3x); Dobrá postava; Práce s tělem; Pohyb (7x); Pohyb je zdravý (6x); Aspoň trocha pohybu (3x); Alespoň nějaký pohyb; Aktivita (2x); Posilování (2x); Posílení těla; Rozvoj těla a svalstva; Spalování tuků (3x); Prospívá zdraví (8x); Zdraví (6x); Podpora zdraví (3x); Lepší zdravotní stav (3x); Pro zdraví; Šetrný ke zdraví; Udrží vás fit; Posiluje imunitu; Pro určité sporty pozitivní zdravotní účinky; Zlepšuje koordinaci celého těla; Člověk neztloustne.

Celkem 109 vyjádření.

6. Postoje k výkonu, výkonnosti, soutěžení, úspěchu

Zdravá soutěživost; Není potřeba být nejlepší; Nedůležitý výsledek pro osobní požitek; Možnost srovnání s ostatními; Zlepšení dovedností.

Celkem 5 vyjádření.

Celkem 449 kladných vyjádření seřazených do 6 kategorií..

Můžeme konstatovat, že studenti vyjádřili obdobné názory jako jiní studenti ve studii zkoumající Motivy ke sportu (Valjent, 2007). Rekreační sport proto ponejvíce vnímají jako nositele zábavy (59 vyjádření), dobré fyzické kondice (51x) a odreagování a relaxace od každodenních problémů (41x). K tomu se zde ještě přidávají motivy individuální nezávislosti, volnosti a časové flexibility (celkem v této kategorii 67 vyjádření). Individuální vnímání je však přirozeně značně různorodé a tím také zajímavé.

\section{Negativa rekreačního sportu \\ 1.Finance}

Finanční náročnost (26x); Omezené finanční prostředky (2x); Na vlastní náklady (4x); Nutnost finančních prostředků; Více sportů - více vybavení - více financí $(2 \mathrm{x})$; Placení míst, kde sportujeme (2x); Finančně náročné vybavení (6x).

\section{Celkem 43 vyjádření.}

\section{2.Časová náročnost a pravidelnost}

Časová náročnost (17x); Žrout času (5x); Časová obět'; Chybí pravidelnost - lenost (4x); Nepravidelnost (4x); Upřednostnění důležitějších věcí, sportu se ustoupí (3x); Nestálost (2x); Nevěnuji se tak často, jak bych chtěla; Člověk musí najít čas, chut' a náladu; Ne vždycky je na něj volný čas; Obtížnost domluvy a nalezení vhodného času; Obtížné dodržování pravidelnosti; Ne vždy udrží pravidelnost; Závislost na počasí. Celkem 43 vyjádření.

\section{Zdraví}

Riziko zranění (21x); Občasné zranění; Riziko zranění kvůli neznalosti sportu; Nepřipravenost a z toho vyplývající úrazy; Tělo není dostatečně připravené na nějakou větší zátěž (2x); Také může mít negativní vliv na zdraví; Nehody; Může vést ke zdravotním problémům (bez trenéra); V létě alergie; Jsem unavený (4x); Bolí svaly; Pěší tůry ve vedru; Opotřebení těla.

\section{Celkem 37 vyjádření.}

\section{Další bližší negativa rekreačního sportu}

Nedostatek tréninkových míst (pro ty méně obvyklé sporty); Sezónní nedostupnost; Ne vždy ideální vybavení (2x); Horší podmínky pro sport; Nemožnost použití správné sportovní pomůcky; Neznalost pravidel; Nemusí být vykonáván přesně podle pravidel (2x); Nevíme, jestli cvičíme správně (2x); Naučení se špatných návyků; Není tak kvalitní; Nedá se tím vydělávat; Nízká úroveň profesionality (průměrné dovednosti); Těžší dosáhnout překonání sama sebe (2x); Nedocílení větších výsledků (2x); Nevydá se maximum (2x); Nic nenutí zlepšovat se $(2 \mathrm{x})$; Neděláme jako u vrcholového sportu - polovičaté; Malá soutěživost; Ležérní přístup; Až přílišný amatérismus; Malé zatížení; Nedostatečné naplnění; Nejsou vidět výsledky; Člověk se nezlepšuje (3x); Pokud se nedělá často, nemá efekt; Žádná profesionální dráha; Rozdíly v umu; Rozdíly ve výkonnosti mezi družstvy; Neumětelové, kteří ...; Antitalenti; Nedostatečná motivace (6x); Neorganizovanost; Nezlepšuje zdraví; Nedostatečná kondice; Není zapotřebí kondice; Zásadně nezlepšuje postavu; Nutnost mít dobrou náladu; Někdy nuda (2x); Nebaví mne; Přehnaná soutěživost (2x); Nucené akce od kamarádů (2x); Občas špatná dostupnost; Špatné počasí $(2 \mathrm{x})$; Omezení počasím a prostorem. 
Za největší negativa rekreačního sportu studenti považují finanční a časovou náročnost, všímají si také rizika zranění. Z jejich bližších vyjádření lze zaznamenat především ten fakt, že volnost a neorganizovanost rekreačního sportu braná celkově jako klad na druhou stranu plodí mnoho nesnází - např. potíže při zorganizování pohybové akce, při stanovení intenzity cvičení, malou či velkou soutěživost, nestejnou výkonnost, dodržování pravidel ad. Nutno také připomenout, že 37 studentů do kolonky negativa rekreačního sportu nenapsala nic, nebo rovnou ,žádné”.

\section{Klady vrcholového sportu}

\section{Bližší kladná charakteritika vrcholového sportu}

Z koníčka se stala práce (12x); Práce, která člověka baví (7x); Zůstane u něj jako trenér $(2 \mathrm{x})$;

Životní cíl; Životní styl; Trenér = rodina; Efektivní využití "volného času”; Širší možnost výběru druhu sportu; Možnost být v něčem dobrý (3x); Dokázat něco; Naplnění ambicí; Možnost viditelného úspěchu (2x); Možnost skutečně něčeho dosáhnout (2x); Zdokonalení v oblíbeném sportu; Stal se životním stylem, posedlostí a smyslem života; Tréninkový system (4x); Soustředění; Kvalitní zázemí - trenér, sportoviště (4x); Ideální treninkové podmínky (vybavení, dostatek času, zkušenosti a pomoc trenérů); Profesionální péče; Dodržování pravidelnosti (3x); Klubové výhody; Možnost pro soutěživé; Zábava pro diváky a fanoušky (3x); Hezky se na to kouká (2x); Show pro ostatní; Inspirace; Tvoří silnou část ekonomiky; Adrenalin (2x); Napětí; Vybití agresivity; Prudké emoce; Uznávám sport, který není jen o penězích $(2 \mathrm{x})$; Jen tanec, ten alespoň nějak vypadá.

Celkem 69 vyjádření.

\section{Postoje k finančnímu zabezpečení}

Možnost vydělat peníze (23x); Dá se tím vydělávat (6x); Možnost ohodnocení (finance); Možnost výdělku; Finanční ocenění a zabezpečení (9x); Trvalý př́ijem; Platí mi za něj Člověk se s ním může živit; Bývá finančně odměňován; Možnost vysoké ekonomické renty;

Sponzoři (2x); Práce.

Celkem 48 vyjádření.

\section{Postoje k rozvoji osobnosti, charakteru, morálně - volních vlastností.}

Překonávat sebe sama (4x); Člověk ze sebe vydá maximum (2x); Překonávání možností lidského těla; 100\% úsilí; Být lepší než ostatní; Motivace být lepší (5x); Hledání lidských limitů; Kázeň; Silná vůle; Výdrž; Vytrvalost; Sebekázeň; Seberealizace (2x); Disciplína; Snaha se zlepšovat; Touha po zlepšení; Princip dřina - výsledky; Trénování soustředění; Povinnost cvičení; Zodpovědnost k prŕípravě; Reprezentace sebe sama a svých vlastností; Získání nových zkušeností; Výrazné zlepšení v určitém směru (2x); Správná výchova jedince pro život; Donucení k vyšším výkonům; Pobídka ke zvyšování výkonu; Poznání prohry; Naplnění svých snů; Pocit z dobře vykonané práce; Donutí ho to věnovat se i 3 - 4 dalším sportům; Pravidelný režim a dril; Správná výživa. Celkem 42 vyjádření.

\section{Postoje k zábavě, sociálnímu kontaktu, přátelství}

Zábava (2x); Týmoví přátelé (2x); Stálí kamarádi; Dobrá parta; Kolektiv; Kolektivnost; Týmová hra (2x); Společný cíl; Přátelé; Noví známí; Seznámení s lidmi stejného zájmu (2x); Poznání vrcholových sportovců; Poznání zajímavých lidí; Zájem druhého pohlaví; Př́ijemně strávený čas, Zážitky, které se jinde nezažijí; Děláme to, co nás baví.

Celkem 21 vyjádření.

\section{Postoje k relaxaci, kompenzaci, snižování tenze, radosti z pohybu}

Dobrý pocit z výkonu (4x); Pohyb; Duševní síla; Vyrovnanost; Zážitky; Radost z výkonu; Dobrý pocit; Psychická pohoda; Uvolnění stresu; Cestování (14x); Poznávání zemí $(2 x)$; Celosvětová soutěž. Celkem 29 vyjádření.

\section{Postoje k zdatnosti, zdraví a dokonalému vzhledu}

Skvělá kondice (34x); Výborná fyzická zdatnost (12x); Zdraví (3x); Zdravý životní styl (2x); Pravidelný pohyb (3x); Zvýšená odolnost; Trénování správného držení těla; Dokonalost těla (2x); Pěkné vypracované tělo (2x); Krásná těla.

Celkem 61 vyjádření.

\section{Postoje k výkonu, výkonnosti, soutěžení, úspěchu}

Výsledky (4x); Soupeření; Výhry a vítězství (2x); Soutěživost (5x); Prestiž; Věhlas; Společenské uznání (8x); Publicita; Ocenění; Veřejná známost (2x); Ohodnocení; Dobrý pocit z ocenění; Sláva a obdiv (13x); Úspěch (8x); Popularita (4x); Zájem okolí; Mediální prosazení; Umístění; Člověk je v něčem dobrý (2x); Pocit, že jsem 
v něčem dobrý (3x); Radost z vítězství (2x); Mezistátní význam medaile; Reprezentace vlasti (6x). Celkem 70 vyjádření.

\section{Celkem 340 kladných vyjádření roztř́iěných do 7 kategorií.}

Studenti si všímají faktu, že koníček se stává prací, která jistě pak i baví (21x) a také přináší i finanční zabezpečení (celkem až 48 vyjádření). Vrcholovým sportovcům je přisuzována skvělá fyzická zdatnost a většinou i pěkně vypracované tělo (celkem 61x), sláva, úspěch a popularita. Studenti př́ijemně překvapili jasným pojmenováním všech př́nosů pro rozvoj osobnosti, charakteru a morálně - volních vlastností (celkem až 42 pojmenování). Objevovali se zde i prvky ve shodě s rekreačním sportem - zábava, přátelé, psychická pohoda, zážitky, cestování apod.

\section{E.Negativa vrcholového sportu \\ 1. Osobní}

Může vytěsnit duševní činnost - školu, vzdělání (3x); Obětování vzdělání (3x); Obětování osobního života (2x); Podřízení osobního života jen sportu (2x); Ztráta dětství; Obětovat tomu celý život (2x); V mysli vrcholového sportovce je sport nejdůležitější, avšak o neskonale důležitější věci přichází; Jednostranný rozvoj člověka (3x); Téměř žádný jiný sociální život (2x); Závislost na druhých; Stává se z něj povinnost (4x); Žádné soukromí; Psychická zátěž; Př́lišné nároky (2x); Neúspěch; Těžké se prosadit; Ženy vypadají jako muži $(2 x)$; Finanční náročnost (21x); Finanční nedostupnost; Finanční nároky na vybavení (3x); Některými sporty nelze uživit rodinu.

\section{Celkem 58 vyjádření.}

\section{Morální}

Doping (10x); Steroidy (2x); Krůček od steroidů; Podpůrné prostředky; V současnosti není čistý; Byznys; Obrovský byznys; Jde o peníze více jak o sport; Výsledek na úkor sportu (2x); Korupce (2x); Ztrácí se smysl pro fair - play; Nespravedlnost (rozhodčí, rivalita); Agresivita; Snaha po výkonu za každou cenu; Pouhá honba za výsledky; Tlak na výkon; Požadují se určité výsledky; U zprofanovaných sportů (fotbal, hokej) jde o nesmyslně objemný tok financí; Sportovní výdělek za zápas jak hasiči za 10 let; Sport jako obživa; Nesvoboda; Dril; Ztráta radosti z pohybu.

\section{Celkem 35 vyjádření.}

\section{Společenská}

Ničí veškeré ostatní aktivity (3x); Mnoho omezení; Málo soukromí (2x); Nesmyslný tlak na jedince; Všechno se točí okolo konkrétního sportu; Př́lišná rivalita (2x); Stane se nezdravou závislostí (2x); Prohra je oceněna spíše zlobou; Podněcuje k pasívnímu sportu - radilové v hospodě; Při úspěchu závist okolí; Medializace (2x); Pod stálým dohledem; Př́lišná veřejná známost; Tlak okolí; Publicita; Přílišné nároky (2x); Povinnost (4x); Nutnost účasti; Člověk musí být nadaný (3x).

Celkem 31 vyjádření.

\section{4. Časová}

Časová náročnost (38x); Časová zaneprázdněnost (6x); Málo volného času (18x); Žádný volný čas; Pravidelnost (2x); Nutnost setrvat i přes časový pres; Neustálý trénink; Neustále mimo domov; Málo času na rodinu; Málo času na prátele (2x); Málo času na sebe; Absence volného času; Cestování - čas v buse; Konec v brzkém věku; Věkové omezení (3x); Sport do určitého věku; Nedá se jím živit věčně.

Celkem 80 vyjádření.

\section{Zdravotní}

Zranění a úrazy (34x); Zdravotní potíže (10x); Škodlivý vliv na zdraví (3x); Ničí do jisté míry tělo; Výkony na úkor zdraví (6x); Ničení těla (6x); Přetěžování těla (16x); Přetěžování určité části těla (2x); Nadměrná fyzická zátěž (5x); Extrémní vytíženost; Vyčerpání; Možnost zranění - konec kariéry (2x); Těžký návrat po zranění (4x); Velký nápor na tělo (2x); Občas huntování těla (6x); Profi sportovci rychleji zestárnou; Opotřebení těla (6x); Rychlé opotřebování těla; Devastace pohybového ústrojí (2x); Zranění kloubů - kolen a kyčlí (4x); Bolesti kloubů, které neustanou (2x); Bolestivé zranění svalu (3x); Nadměrné zatěžování těla a kloubů (2x); Jednostranné zaměření (7x); Velká únava $(2 \mathrm{x})$; Dřina $(2 \mathrm{x})$; Náročný trénink $(4 \mathrm{x})$; Náročná prŕíprava; Celková náročnost na organismus; Nápor na tělo; Náročnost; Zdraví; Nesmí být nemocný; Omezování stravy; Nervy (2x); Stres (6x); Náročné na psychiku; Velký př́ijem potravy; Omezování ve stravě (3x); Pití alkoholu.

\section{Další blíže nezařaditelná}


Nelze vykonávat více sportů na vrcholové úrovni; Hnusí se mi sporty jako fotbal, hokej (2x); Soutěžení s ostatními; Dodržování správné životosprávy (3x); Nic.

Celkem 8 vyjádřrení.

\section{Celkem 368 záporných vyjádření.}

Studenti zde jasně pojmenovali širokou paletu negativ vrcholového sportu. K nim patří zejména všechny zdravotní a tělesné problémy (celkem až 156 vyjádření) vrcholových sportovců, všechny osobní oběti pramenící především z velké časové náročnosti (až 80 vyjádření) vedoucí k podřízení osobního života jen sportu. Při cestě za svým cílem jsou pak často konfrontováni s morálním úpadkem $(35 \mathrm{x})$ a různými společenskými omezeními (31x), s nimiž si bez žádných problémů poradí jen velká osobnost. Někteří studenti si všimli i vysokých finančních nároků v mládežnické vrcholovém sportu (celkem 25 vyjádření), díky nimž se mu vlastně nemohou věnovat úplně všichni talentovaní. Celkem 7 studentů neshledalo na vrcholovém sportu žádných kladů.

\section{Závěr}

Studenti ČVUT vyjádřili celkově 1342 svých vyjádření vůči rekreačnímu a vrcholovému sportu, což činí průměr 9,2 vyjádření na jednoho. Mají v průměru velice kladný poměr ke sportu, o čemž svědčí průměr na Likertově 11-bodové škále $(+3,15)$.

Splnil se předpoklad o rekreačním sportu, když kladných vyjádření bylo celkově 449 oproti 185 záporným. To činí poměr 2,42 ve prospěch kladů. Studenti zde jasně vyjmenovali všechny hlavní klady rekreačního sportu - nezávislost, volnost a časovou flexibilitu, zábavu, relaxaci a udržení fyzické kondice; naznačili ovšem i jeho největší nedostatky - finanční a časovou náročnost, možnost zranění. Odhalili však i protikladnost hlavních vyjádření. Všechny vyjmenované hlavní devizi rekreačního sportu ve svém celku totiž zároveň plodí i jeho velké nedostatky. Mezi ně studenti řadí již obtíže při vlastním zorganizování sportovní akce, dodržování sportovních pravidel, nestejnou výkonnost, nízkou či vysokou intenzitu, potřebnou pravidelnost a další. Všechny tyto zjištěné výtky dokáže eliminovat organizovaná vysokoškolská tělesná výchova.

Studenti sice odhalili všechny zápory vrcholového sportu (celkem 368 vyjádření), všímali si však na druhé straně i jeho velkého počtu pozitiv (340). Za klady studenti považují jeho př́nosy pro rozvoj morálně-volných vlastností, vysokou fyzickou připravenost, možnost živit se svým původním koníčkem a také všechny kolektivní zážitky. Plně si však uvědomují i hlavní negativa - zdravotní problémy, jednostranné životní zaměření, problémové morální a společenské aspekty.

Při analýze výsledků byly zjišsěny velké rozdíly, ba přímo i protiklady při nahlížení jednotlivými studenty na jednotlivé aspekty. Co se líbí jednomu, nelíbí se druhému; jednu a tutéž věc má jeden za klad, druhý za zápor. Za prríklad mohou sloužit u vrcholového sportu následující vyjádření - pravidelný režim, dril, publicita, sláva, cestování, (ne)zdravá soutěživost apod.

\section{Literatura}

Bílá kniha o sportu (2008). Praha : MŠMT.

Evropská deklarace urbanistických práv (1992). URL: < http://www.veda.cz/findInSection.do? sectionId=1252\&categoryId=3775> [cit. 2006-8-8].

Evropský manifest o mladých lidech a sportu (1995). Praha : MŠMT.

Evropská charta sportu (1994). Praha : MŠMT.

Flemr, L., Valjent, Z. (2010). Socializace sportem. Studia sportiva, 4 (1), 71 - 88.

Jansa, P. (2002). Názory (postoje) a zájmy adolescentní mládeže o sport, tělesnou výchovu a jiné pohybové aktivity. Česká kinantropologie, 6 (2), 23-39.

Kavalír̆, P. (2003). Pozice sportu v hodnotových systémech a preferencích žáků středních škol. Disertační práce (vedoucí P. Slepička). Praha : UK FTVS.

Králík, M. (2001). Sportovní legislativa na prahu třetího tisíciletí. In Tilinger, P., Rychecký, A., Perič, T. (ed.) Sport v České republice na začátku nového tisíciletí 1. Praha : UK FTVS, s. 467-468.

Modifikovaný návrh směrnic pro sport dětí a mládeže (1998). Praha : ČSTV.

Sméry státní politiky na léta 2004-2006. <http://www.msmt.cz/Files/TVS/Sport/2003/SMERY_STATNI_POLITIKY_R.doc> [cit. 2007-5-5].

Okamura, T. (2011). Umění vládnout. Praha: Fragment. ISBN 978-80-253-1253-7.

Rychtecký, A. aj. (2000). Monitorováni účasti ve sportu a pohybové aktivitě v České republice a v evropských 
STUDIA SPORTIVA 2012/6, č. 2, s. 92-99

zemích. Závěrečná zpráva grantu MŠMT ČR. Praha : UK FTVS.

Rychtecký, A. (2001). Monitorování účasti mládeže ve sportovních a pohybových aktivitách v České republice a v evropských zemích dle metody COMPASS. In P. Tilinger, A. Rychtecký a T. Perič (ed.) Sport v České republice na začátku nového tisíciletí 2. Praha : UK FTVS, s. 66-70.

Sekot, A. (2003). Socializace sportem - nezastupitelná součást výchovného procesu. Referát prezentován na 11. konferenci ČAPV - Sociální a kulturní souvislosti výchovy a vzdělávání.

URL: <http://www.ped.muni.cz/capv11/4sekce/4_CAPV_Sekot.pdf> [cit. 2006-18-10].

Sekot, A. (2007). Sociologický pohled na sport: konceptuální východiska. Česká kinantropologie, 11, 1, s. 53-61.

Sekot, A. (2003). Sport a společnost. Brno: vydavatelství Paido. ISBN 80-7315-047-6.

Slepička, P. (2000). Sport a česká společnost. In Slepička, P., Slepičková, I. (ed.) Sport, stát, společnost. Praha : UK FTVS, s. 9-22.

Svoboda, B. (1971). Výzkum postojů sportovního trenéra. AUC Gymnica, 2, 65-73.

Valjent, Z. (2007). Motivace ke sportu u studentů FEL ČVUT v Praze. In.: Sborník z mezinárodní konference Optimalizácia zat’aženia v tělesnej a športovej výchove na rozličné formy pohybového zat’aženia, pp. 227- 233. Bratislava: Strojnícka fakulta STU.

Weiss, O. (2000). Sport jako společenský jev. In Slepička, P., Slepičková, I. (ed.) Sport, stát, společnost. Praha : UK FTVS, s. 40-51.

Zich, F., Ungr, V. (1995). Tělovýchovné a sportovni aktivity mládeže (Výsledky empirického sociologického výzkumu). Zpracováno v rámci grantu MŠMT ČR. Praha : Amasia. 